\title{
Humanism Counseling: Finding Gaps in the Concept of Religious Guidance and Counseling in Indonesian Government Regulation (Normative Study of Government Regulation No. 111/2014)
}

\author{
Indri, Usman Abu Bakar, and Abdul Matin bin Salman \\ Post Graduate, State Islamic Studies (IAIN) Surakarta, Central Java, Indonesia \\ Professor and Rector, Cokroaminoto University, Yogyakarta, Indonesia \\ Ph.D, Faculty Ushuluddin and Dakwah (IAIN) Surakarta, Central Java, Indonesia \\ Email: indrichairunnissa899@gmail.com, usman.iainsolo@gmail.com, and \\ abdulmatinbinsalman4@gmail.com
}

\begin{tabular}{|c|c|}
\hline ARTICLE INFO & ABSTRACT \\
\hline $\begin{array}{l}\text { Date Received : } 01 \text { December } 2020 \\
\text { Revision Date : } 03 \text { February } 2021 \\
\text { Date Received : } 07 \text { May } 2021\end{array}$ & $\begin{array}{l}\text { This paper finds and explains the side of the discussion of } \\
\text { religion in government regulation no. } 111 / 2014 \text {. The } \\
\text { results show that there is no vacancy in the discussion of }\end{array}$ \\
\hline $\begin{array}{l}\text { Keywords: } \\
\text { Humamism } \\
\text { Guidance } \\
\text { Counseling } \\
\text { Regulation } \\
\text { Islam } \\
\text { Indonesia }\end{array}$ & $\begin{array}{l}\text { religion in this regulation. One of the functions of } \\
\text { guidance and counseling services is understanding, which } \\
\text { is to help counselees have a better understanding of } \\
\text { themselves and their environment (education, work, } \\
\text { culture, and religious norms). In its application, guidance } \\
\text { and counseling services in educational units as a whole } \\
\text { are packaged into four service components, one of which } \\
\text { is the basic service component, where the main objective } \\
\text { is an effort to help counselees have awareness } \\
\text { (understanding) of themselves and their environment } \\
\text { (education, work, social culture, and religion). While the } \\
\text { concept of communication guidance and counseling } \\
\text { services that religion is a fixed(intended)and services that } \\
\text { are not fixed (unintended), which subsequently gave birth } \\
\text { to concepts counseling humanism. }\end{array}$ \\
\hline
\end{tabular}

\section{INTRODUCTION}

The terms guidance (guidance) and counseling (counseling) have a very close relationship and are integral activities. In terms of daily practice, guidance is always coupled with the term counseling that guidance and counseling (guidance and counseling). Guidance is a process of providing continuous and systematic assistance to individuals to solve the problems they face. The purpose of the guidance service is so that the counselee can: (1) plan study completion activities, career development, and life in the future; (2) develop all the potential and strength they have to the maximum; (3) adapt to the educational environment, community environment and work environment; (4) overcoming obstacles and difficulties faced in studies, adjusting to the educational environment, society, and work environment. Some parties think that there is no principal difference between guidance and counseling or both have identical meanings. However, some argue that guidance and counseling are two different definitions, both the basis and the way they work. Counseling or counseling is considered synonymous with psychotherapy, which is the effort to help people who have a serious mental disorder, 
while guidance is considered synonymous with education. Meanwhile, others argue that counseling is one of the techniques for providing services in guidance and is the core of all guidance services (Lattu, 2017).

Anderson said that the improvement of the quality of education is also closely related through responsive support and innovation (Anderson et al., 2018).

Akmal Mundiri said education was prone in terms of quality. This has an impact on the implementation of the communication process in education itself, between educators and students. (Mundiri, 2017) Hussein Amzat said that there is a side where educational institutions should be able to identify educational service programs that are no longer significant in line with the goals of education itself. (Amzat et al., 2020) In line with this, Brady and Bates mention the need for "Quality Culture" in ensuring that the educational process is appropriate in line with its objectives. Among them is the communication that exists between human resources in educational institutions. (Brady \& Bates, 2016) In responding to the development of the times, religious guidance is the best solution as a way of developing human resources. (Ashari et al., 2017) Religious guidance is currently urgent for the education curriculum (Yahiji et al., 2018).

New construction is needed in terms of teaching and learning in Indonesia to prevent various understandings that have the potential to damage or diverge (Rosser, 2016). Islamic guidance and counseling not only helps overcome the problems of students related to their learning but also touches the religious aspects of students, however, religion has a very important role in human life to regulate and control the life of their actions. what is not good becomes a useful life, both worldly life, and the afterlife (Nuraeni et al., 2020). In line with this, Saada and Gross said that teacher guidance formed them to think critically, have moral attitudes, and deliberate thoughts. (Saada \& Gross, 2017) Meanwhile, the phenomenon of commercialization of education has distanced students from the side of character planting (Hadiningrum, 2017).

Islam is closely related to education. The concept of education is directed at the formation of human and civil society where the ultimate goal is the realization of the main human beings globally. This is where the role of educational institutions (Hadiningrum, 2017).

Abdul Basit said that from the perspective of historical challenges, it can be seen that the challenges for Islamic extension agents are not getting lighter, but more challenging and complex. Islamic religious extension workers are faced with various changes that have occurred in Islamic society and also in human life globally. As a result of advances in science and technology, the mindset and behavior of the Indonesian people and the world community have experienced very significant developments. In the era of Indonesian reform (1998) where the taps of freedom were wide open and the democratic process began to grow in quality, it was precisely among the Muslim community that radical and fundamentalist Islamic movements grew. On the one hand, the presence of these religious organizations enlivened the Islamic da'wah movement in Indonesia, but on the other hand, the emergence of these organizations raised several problems that troubled the community and even cornered the image of Islam. One of them is various cases of suicide bombings. Muslims cannot be separated from global currents that carry the themes of democratization, upholding human rights, gender mainstreaming, secularization, environmental preservation, and various other themes. Muslims need to take a big share in formulating these global concepts and strive to be able to apply them in the life of the nation and state. Muslims cannot be exclusive and close tightly on the circulation of information and changes in society that are increasingly dynamic and progressive. Islamic or religious extension workers are also faced with challenges related to improving the morality of the Indonesian nation. Various cases of morality whacking this nation are increasingly concerning, including corruption, drug abuse, HIV/AIDS, environmental destruction, and free sex among students. Even though the Indonesian nation is known as a country with the largest Muslim population in the world and as a supplier to the largest number of pilgrims in the world (Basit, 2014).

The main objective of educational institutions is to create human beings with character and competence. Education is the 
way to create an ideal nation. Also, it was also stated that the cultivation of the importance of education became the basis for students as individuals to be able to make positive changes. (La Fua et al., 2018) As an illustration, Madrasas in Singapore also teach their students materials related to the development and policies/direction of the State (Mohd Nor et al., 2017). One of the biggest homework in the world of education in Indonesia in practice is the low focus on character guidance or mental development (Sulisworo, 2016) Based on this description, the writer intends to discuss the concept of guidance and counseling in the Regulation of Government Regulation No. 111/2014 of especially in terms of religious guidance and counseling.

Government Regulation No. 111/2014 states Guidance and Counseling is basically a systematic, objective, logical, sustainable, and programmed effort carried out by counselors or guidance and counseling teachers to facilitate the development of students/counselees to achieve independence in their lives. Government Regulation No. $111 / 2014$ in its legal basis can be explained as follows:

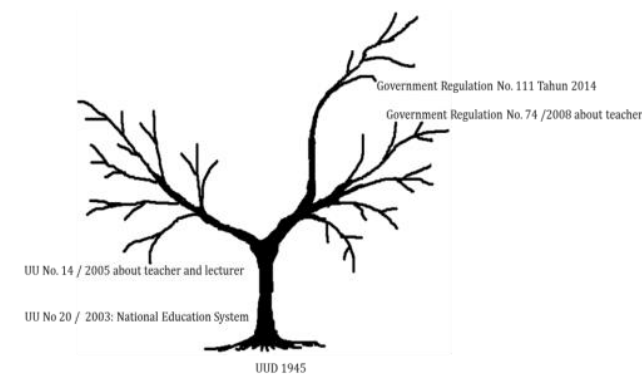

\section{Picture 1: Regulation Guidance and Counseling Tree}

Based on the picture above, it can be seen that Government Regulation No. $111 / 2014$ has met legally as an extension of the regulations above, rooted in the 1945 constitution. The differences between general guidance and counseling and Islamic guidance and counseling according to Thohari Musnamar, include: first in general, in the West, there is a process of guidance and counseling services not connected with God or religious teachings. So guidance and counseling services are considered as purely worldly matters, whereas Islam recommends that the activity of guidance and counseling services is a form of worship to Allah SWT assistance to others, including guidance and counseling services, in Islamic teachings, it is counted as a charity. Second, there is generally a concept of western guidance and counseling services based solely on the human mind. All existing guidance and counseling theories are only based on past experiences, while the concept of Islamic guidance and counseling is based on, namely, the Qur'an and the Sunnah of the Prophet, the activities of reason and human experience. Third, the concept of western guidance and counseling services does not address the problem of life after death. Meanwhile, the concept of Islamic guidance and counseling services believes in life after death. Fourth, the concept of western guidance and counseling services does not discuss and associate itself with merits and sins. Meanwhile, Islamic guidance and counseling discuss the rewards and sins that have been done (Siregar, 2020).

The techniques used in data collection as part of the guidance and counseling of students can be used either test techniques or non-test techniques. (Compilation Team. 2013 Curriculum Implementation Training Module: 61) Test techniques that can be used in guidance and counseling can be in the form of psychological tests. Non-test techniques that can be used in guidance and counseling include the following techniques: first, documentation, as a technique for obtaining data on learning achievement based on student report cards (academic achievement), award certificates, and nonacademic achievements. This data can be used for the analysis of students' learning abilities, which is a reflection of seriousness in learning, general intelligence, and special intelligence, which are interpreted as being relevant to the subject being taken with the field of expertise. Second, questionnaires, as a technique for obtaining data about (for example) students' learning interests, parental attention, and aspirations. Third, interviews, as a technique that can be used to clarify the questionnaire and other necessary matters. Fourth, observation, as a technique that can be used to obtain data on physical conditions and behavior that appear to be taken into consideration.

Harapan terhadap kualitas individu dalam bimbingan dan konseling, khususnya dalam perspektif Islam, muncul sebagai 
bagian dari proses pemahaman bahwa setiap individu memiliki unsur penting dalam membangun hak asasi. Untuk itulah diperlukan pengenalan konseling sejak dini kepada setiap individu (Martensson and Eriksen, 2018).

The term "Humanism" is an invention of the 19th century. In German, this language is known as Humanismus, a term first used in 1808 to refer to the form of education which provided the main place for the mastery of Latin and Latin. In English, "humanism" began to appear somewhat later. In terms of language, "humanism" comes from the Latin word humanism and has a root word meaning homosexual man. Humanus means "according to human nature". Initially, humanism was a movement that emphasized human dignity and values. As part of a critical school of thought originating from a movement that upholds human beings, humanism emphasizes the dignity, role, and responsibility of humanity. Humanism itself is always associated with a philosophical view that places humans in a certain position and makes them the measure of everything. Furthermore, since the seventeenth century, what is called humanism has been obliged to rely on certain conceptions of man borrowed from religion, science, or politics. Humanism serves to color and justifies the conception of man in which he must take a way out. (Hamdi Usman, 2017) Hamdi Usman said the concept of humanist education is in line with the education system in Indonesia, where it is directed to produce independent and responsible human resources that embody the concept of Indonesian national education. This formulation is a principle that upholds human rights in a humanist vision (Usman et al., 2017)

Azaki Khoirudin said that communication between teachers and students can reach a humanist level if it can restore human function to its original purpose, namely to become the human being desired by God, and to achieve a real social and social environment. willed by God too (Khoirudin et al., 2020). Ahmad Fauzi illustrates that this relationship or communication pattern exists in Islamic boarding schools as the relationship between Kyai and Santri (Fauzi, 2017).

Darmalaksana said humanist education in Indonesia was an implementation of existing regulations. In this case, the Teacher and Lecturer Law states that educational tasks are closely related to learning, research, and social services. Educators implement all three in activities that support the development of the potential of students, in line with the objectives of guidance and counseling (Darmalaksana, 2017) Eissa and Khalid base humanists if education has been able to give birth to personal figures who have the character on the one hand and have the ability for themselves and society on the other (Eissa \& Khalid, 2018). Educational changes basically lead students to not only know "Knowing That", but also "Knowing How", in line with humanist education that offers complete human capabilities (Orrell \& Conway, 2016).

\section{METHOD}

The research conducted is a type of normative research (literature). Tracing this written data, through laws and related books on religious guidance and counseling. This study concentrates on Governement Regulation No. 111 of 2014 on Bimbingan dan Konseling Pada Pendidikan Dasar dan Pendidikan Menengah. The data collection technique used in this study uses documentation. Meanwhile, the analysis used in this research is descriptive qualitative. The analysis is carried out through, first, data collection in the form of laws and regulations which are the object of research; second, reducing data through categorization or initial identification to determine the topics that will be used; third, present the data presented in writing or verbal words systematically; and fourth, conclude.

\section{RESULTS AND DISCUSSION}

The results of education should ideally be known to what extent it can transform the knowledge, character, and expertise of students. (Mukaddes et al., 2012)The complexity of education in Indonesia is one of them is moral (Nurdyansyah, 2017). (Marshallsay, 2012) underlines the importance of additional activities in the educational process as part of religious teaching and knowledge transformation. Furthermore, it is said that the transfer of knowledge and knowledge in the Muslim education environment is considered 
successful considering the closeness between educators and students. From an Islamic education perspective, it is found that complex problems in the world of education require control in every identification and problem solving, especially in developing curriculum. (Rahmawati et al., 2018) (Yahiji, 2018). The curriculum must have relevance to social development (Lubis et al., 2019).

The legal basis for Religious Guidance and Counseling, among others, is first, educating the nation's life is one of the goals of education, the success of education is inseparable from the quality of education that can realize the success of learning from an individual. Second, education is a planned effort in the process of mentoring and learning for individuals to develop and grow into human beings who are independent, responsible, creative, knowledgeable, healthy, and have noble character. Law No. 20 of 2003 concerning the National Education System (Sisdiknas) asserts, "National education functions to develop capabilities and shape the character and civilization of a nation with dignity to educate the nation's life, aims to develop the potential of students to become human beings who believe and fear God Almighty, have a noble character, are healthy, knowledgeable, capable, creative, independent, and become democratic and responsible citizens "(article 3). From this formula, it can be seen that national education has a mission that is not easy, namely to build a complete and complete human being who has great character values as well as having faith and piety. That's why education becomes the agent of change that must be able to improve the character of the nation. Third, Government Regulation No. 111/2014 states that Guidance and Counseling is a systematic, objective, logical, sustainable, and programmatic effort carried out by counselors or guidance and counseling teachers to facilitate the development of students/counselees to achieve independence in their lives. If it is further discussed, it can be explained that the Government Regulation Number 111/2014 contains:

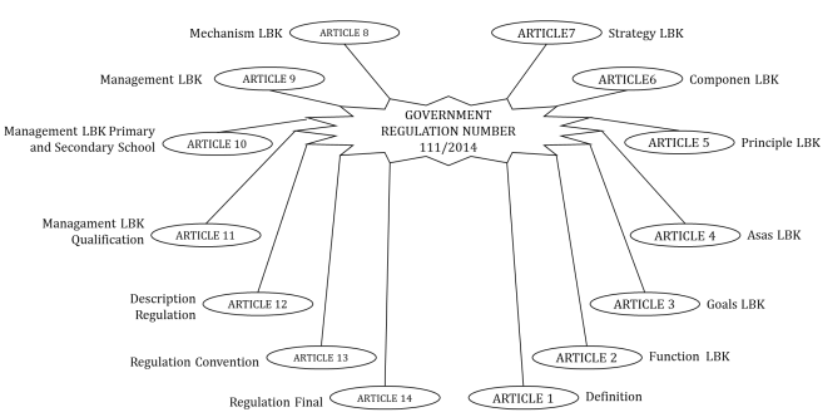

Picture 3: Government Regulation No. $111 / 2014$

The editorial of the word "religion" can be found in the Annex to this Regulation. The attachment to Governemnt Regulation No.111 of 2014 states follows the direction and spirit of the 2013 Curriculum, the guidance and counseling paradigm views that every student/counselee has the potential to develop optimally. Optimal development is not limited to achieving achievements by following with their intellectual capacity and interests, but as a developmental condition that enables students to be able to make healthy and responsible choices and decisions and have high adaptability to the dynamics of life they face. It was also stated that one of the functions of guidance and counseling services is understanding, which is to help the counselee have a better understanding of himself and his environment (education, work, culture, and religious norms). In its application, guidance and counseling services in educational units as a whole are packaged into four service components, one of which is the basic service component, where the main objective is an effort to help counselees have awareness (understanding) of themselves and their environment (education, work, social culture, and religion). From this, it is clear that there is no vacancy in the discussion of religion in Government Regulation No.111/2014. Also, religious counseling guidance as a form of potential optimization needs to be emphasized in its implementation by containing elements in the communication of Religious Guidance and Counseling -Qur'an and Sunnah. The concept of Communication Guidance and Religious Counseling is based on the word of Allah: "O people, a lesson has come from your Lord and a cure for diseases (which are) in the chest and guidance and mercy for those who believe. (Surah Yunus: 57). This shows that basically, BK Religion is an Intended service, 
in the sense that everything will return to the Creator. Furthermore, BK Religion is Unintended, where everything must be sought, as knowledge is learned, as the problem is sought for solutions, and does not necessarily just pray, but also through effort. This is stated as the word of Allah: "And We sent down from the Qur'an something that is an antidote and a mercy for those who believe and the Quran does not add to the wrongdoers other than loss". (Surah Al-Isra ': 82).

Meanwhile, the development of children's potential becomes a consideration in carrying out fundamental activities of guidance and counseling in education. This change does not necessarily change the character of culture into new things but can instill a character that is in line with human values. This is where humanist guidance and counseling emerges as an alternative answer to the implementation of religious guidance counseling also require management so that it can run in line with common goals and expectations, not overlapping with applicable regulations. The concept of humanist guidance and counseling offered in this paper, in line with the communication of Religious Guidance and Counseling is as follows: and counseling. humanist or guidance and

\section{CONCLUSION}

One of the functions of guidance and counseling services is understanding, which is to help counselees have a better understanding of themselves and their environment (education, work, culture, and religious norms). Guidance and counseling services provide the direction of student specialization seriously on the one hand, and on the other hand, the specialization services should not weaken the overall guidance and counseling services. For this reason, it is necessary to formulate a general guide for the implementation of Guidance and Counseling services, especially the Guidance of Religious Counseling. Humanism Counseling is an alternative in offering communication between counselors and counselees in achieving the main objectives of the guidance and counseling itself. Based explanation and conclusion, it would be necessary to study further about humanism counseling include methods and tools engineering. For other researchers are expected to develop further given the limitations in this study which focuses on the regulation of Guidance and Counseling.

\section{REFERENCES}

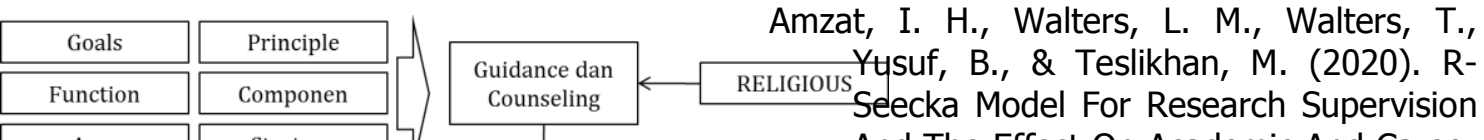
And The Effect On Academic And Career Growth Of International Graduate Students In Malaysia. MOJEM: Malaysian Online Journal of Educational Management, 8(3), 1-20. Google Scholar

Anderson, L., Hibbert, P., Mason, K., \& Rivers, C. (2018). Management education in turbulent times. SAGE Publications Sage CA: Los Angeles, CA. Google Scholar

Ashari, R., Syam, A. R., \& Budiman, A. (2017). The World Challenge Of Islamic Education Toward Human Resources Development. Proceeding of International Conference on Islamic Education (ICIED), 2(1), 169-175. Google Scholar 
Basit, A. (2014). Tantangan profesi penyuluh agama islam dan pemberdayaannya. Jurnal Dakwah, 15(1), 157-178. Google Scholar

Brady, N., \& Bates, A. (2016). The standards paradox: How quality assurance regimes can subvert teaching and learning in higher education. European Educational Research Journal, 15(2), 155-174. Google Scholar

Darmalaksana, W. (2017). Analysis of Research Policy at Islamic Higher Education in Indonesia. The Social Sciences, 12(8), 1428-1433. Google Scholar

Eissa, M., \& Khalid, M. (2018). Development of Character and Life Skills through Islamic Methods of Teaching Acquired Science Subjects at Islamic International Schools in Malaysia. IIUM Journal of Educational Studies, 6(1), 3-17. Google Scholar

Fauzi, A. (2017). Organizational Culture of Islamic Public Education Management a Discurtive. Proceeding International Conference on Islamic Education (ICIED), 2(1), 130-136. Google Scholar

Hadiningrum, L. P. (2017). Islamic Education Reconstruction: Mastery Learning Based in Modern Islamic Boarding School. HUNAFA: Jurnal Studia Islamika, 14(1), 1-15. Google Scholar

Khoirudin, A., Baidhawy, Z., \& Nor, M. R. M. (2020). Exploring Muhammadiyah's Historical Civilizational Dimension Of Social Reconstruction In Indonesia: Humanitarian And Cosmopolitan Approaches. Journal of Al-Tamaddun, 15(1), 183-197. Google Scholar

La Fua, J., Nurlila, R. U., \& Wekke, I. S. (2018). Strategy of Islamic education in developing character building of environmental students in Indonesia. IOP Conference Series: Earth and Environmental Science, 175(1), 12149. Google Scholar

Lattu, D. (2017). Solusi Pelaksanaan
Bimbingan dan Konseling dalam Implementasi Kurikulum 2013. Jurnal Bimbingan Dan Konseling Terapan, 1(1). Google Scholar

Lubis, S. A., Khadijah, K., \& Syahdi, S. (2019). Principles of Islamic Counseling. Benchmarking-Jurnal Manajemen Pendidikan Islam, 3(2), 66-71. Google Scholar

Marshallsay, Z. (2012). Twists and turns of Islamic education across the Islamic world. International Journal of Pedagogies and Learning, 73), 180190. Google Scholar

Mohd Nor, M. R., Senin, N., Mohd Khambali Hambali, K., \& Ab Halim, A. (2017). Survival of Islamic Education in a Secular State: The Madrassa in Singapore. Journal for Multicultural Education, 11(4), 238-249. Google Scholar

Mukaddes, A. M. M., Bagum, N., Islam, M. A., \& Khan, M. M. A. (2012). The application of quality function deployment to improve the teaching techniques in higher education. International Journal of Industrial and Systems Engineering 1, 11(1-2), 97109. Google Scholar

Mundiri, A. (2017). Organizational Culture Base On Total Quality Management In Islamic Educational Institution. ADRI International Journal Of Islamic Studies and Social Sciences, 1(1). Google Scholar

Nuraeni, Y., Zulela, M. S., \& Boeriswati, E. (2020). A Case Study of Curriculum Implementation and $\mathrm{K}-13$ Challenges in Indonesia. International Journal for Educational and Vocational Studies, 2(1), 14-18. Google Scholar

Nurdyansyah, N. (2017). Integration of Islamic Values in Elementary School. Google Scholar

Orrell, J., \& Conway, R. (2016). Integrating graduate attributes into Islamic higher education curricula in Aceh, Indonesia. 
In Publishing Higher Degree Research (pp. 145-154). Springer. Google Scholar

Rahmawati, R., Yahiji, K., \& Mustakimah, M. (2018). Makna Zikir Bagi Jemaah Tarekat Naqshabandīyah Khālídiyah Majelis Pengkajian Tauhid Tasawuf Indonesia Di Kota Gorontalo. Teosofi: Jurnal Tasawuf Dan Pemikiran Islam, 8(2), 325-350. Google Scholar

Rosser, A. (2016). Neo-liberalism and the politics of higher education policy in Indonesia. Comparative Education, 52(2), 109-135. Google Scholar

Saada, N., \& Gross, Z. (2017). Islamic education and the challenge of democratic citizenship: A critical perspective. Discourse: Studies in the Cultural Politics of Education, 38(6), 807-822. Google Scholar

Siregar, A. (2020). ISLAMIC COUNSELING IN
A Philosophy Perspective. International Journal of Islamic Education, Research and Multiculturalism (IJIERM), 2(2), 116-134. Google Scholar

Sulisworo, D. (2016). The Contribution of the education system quality to improve the nation's competitiveness of Indonesia. Journal of Education and Learning, 10(2), 127-138. Google Scholar

Usman, A. H., Shaharuddin, S. A., \& Abidin, S. Z. (2017). humanism in islamic education: indonesian references. International Journal of Asia-Pacific Studies, 13(1). Google Scholar

Yahiji, K., Sukmawati, H., Alfin, J., \& Mahfud, C. (2018). Traffic education in contemporary Islamic education curriculum in Indonesia. Tadarus: Jurnal Pendidikan Islam, 702), 56-69. Google Scholar

\section{Copyright holder: \\ First publication right: \\ Journal of Social Science (JSS)}

Indri, Usman Abu Bakar, and Abdul Matin bin Salman (2021)

This article is licensed under: 